\title{
Suitability of Rural Living \& Work Facilities, Spatial Behavior Patterns of Farmers and Family Income
}

\section{Zrównoważoność ułatwiania życia i pracy na wsi, przestrzenne wzorce zachowań rolników i dochody ich rodzin}

\author{
Yanling Mao*, $\mathrm{Na} \mathrm{Li}^{\star \star}$ \\ School of Management, Nanchang University, Nanchang 330031, Jiangxi, China \\ E-mail:maoyanling@ncu.edu.cn, \\ ORCID: 0000-0002-3151-9935, Scopus ID: 157015982400, \\ **E-mail (Corresponding Author): lina@email.ncu.edu.cn, ORCID:0000-0001-9582-3381
}

\begin{abstract}
In recent years, China has put forward policies to improve rural infrastructure and promote the development of rural industries causing to dramatic transition in the living and employment conditions. Moreover, under the pressure of the high expenditure of living and the difficulty of finding jobs, new changes have taken place in the spatial behavior pattern of farmers' residence and employment. Based on a field survey of 839 observations in 123 villages in Poyang Lake basin, China, we developed indicators to evaluate the suitability of rural living facilities (SLF) and work facilities (SWF). Multinomial logit regression model was used to measure the relationship between SWF, SLF and the spatial behavior patterns of farmers. The results show that: (1) SWF development in rural areas lags behind SLF; (2) Higher SLF is most distributed in suburban areas ; (3) Higher SWF is mostly distributed in suburban towns and characteristic towns; (4) The effects of SLF and SWF on the spatial behavior patterns of farmers are significantly positive; (5) Farmers in the urban-rural amphibious pattern usually obtain a higher income level, and also bring vitality to the countryside.
\end{abstract}

Keywords: suitability of living facilities, suitability of work facilities, spatial behavior pattern, multinomial logit model, rural development, family income

\section{Streszczenie}

W ostatnich latach Chiny przedstawily politykę poprawy infrastruktury wiejskiej i promowania rozwoju przemysłu wiejskiego, powodując istotne zmiany w warunkach życia i zatrudnienia. Ponadto, pod presją wysokich wydatków na życie i występujących trudności ze znalezieniem pracy, nastąpiły nowe zmiany w przestrzennym wzorcu zachowań rolników w miejscu zamieszkania i pracy. Na podstawie ankiety terenowej obejmującej 839 obserwacji w 123 wioskach w dorzeczu jeziora Poyang w Chinach, opracowaliśmy wskaźniki do oceny przydatności ułatwiania życia na wsi (SLF) i ułatwiania pracy (SWF). Do pomiaru związku między SWF, SLF a przestrzennymi wzorcami zachowań rolników zastosowano wielomianowy model regresji logitowej. Wyniki pokazują, że: (1) rozwój SWF na obszarach wiejskich pozostaje w tyle za SLF; (2) SLF jest najbardziej rozpowszechniony na obszarach podmiejskich, podczas gdy; (3) Wyższe SWF są rozprowadzane głównie w miejscowościach podmiejskich i miejscowościach charakterystycznych; (4) Wpływ SLF i SWF na przestrzenne wzorce zachowań rolników jest znacząco pozytywny; (5) Rolnicy funkcjonujący w układzie miejsko-wiejskim zwykle uzyskują wyższy poziom dochodów, a także wnoszą witalność wsi.

Słowa kluczowe: zrównoważoność ułatwiania życia, zrównoważoność ułatwiania pracy, przestrzenny wzorzec zachowań, wielomianowy model logitowy, rozwój obszarów miejskich, dochody rodzin 


\section{Introduction}

At present China, rural areas are weak spots in economic development. Rural development is vital to the stable development of the whole country. The problems resulted in the abandonment of rural areas include mobility, poverty, biased policies and inadequate land management ( $\mathrm{Liu}$ and $\mathrm{Li}, 2017$ ). In order to solve these problems, the Chinese government first proposed Rural Revitalization Strategy in 2017. In 2019, a package of policies has further released following the report of No 1 central document of Chinese government, which charts the roadmap for rural vitalization. Among them, the government put forward the guidelines of rural revitalization strategy, including thriving businesses, pleasant living environment, social etiquette and civility, effective governance, prosperity and out of poverty. In order to improve rural infrastructure and promote the development of rural industries, China has issued many policies. For example, to help disadvantage households to fight poverty, the targeted poverty alleviation policy was designed to taking targeted measures in different regions (Zhou et al., 2018). At the same time, the implementation of land transfer policy aims at achieving farmland scale management, attracting investment, promoting the invigoration of rural land resources and labor, improving the economic efficiency of land and increasing farmers' income (Yuan et al., 2018). Driven by these policies, rural areas in China have experienced a significant transformation through population, employment, and industrial restructuring. Living conditions in the countryside have been greatly improved. Great changes have taken place in the living facilities in the countryside. Brand-new roads have been built to every front door. Every household had clean tap water to drink. Colorful cultural facilities such as activity rooms and libraries have also entered the countryside. Not only that, with the acceleration of rural land circulation, the scale of industrialization is also constantly improving urban-rural integration and industry integration, injecting new vitality to the countryside. China has made great achievements in rural poverty eradication. By the end of 2019, more than 11.09 million rural people in China were lifted out of poverty, contributing to $66.8 \%$ of poverty reduction compared with the previous year. Developments in rural industry also have been a major contributor to China's remarkable GDP and export growth, and absorbing more than $30 \%$ employment of the rural labor force(Long and Woods, 2011). China also has witnessed a big increase in off-farm employment (Li et al., 2021). In 2020, the per capita disposable income of rural residents in the city reached 17131 yuan, an increase of 14170 yuan compared with 2,946 yuan in 2000 .

Despite the tremendous development in rural areas, there is still a serious outflow of people from rural areas, causing a series of problems affecting sustainable development, such as the rapid loss of rural labor force, the weakening of rural population, the idle and waste of rural resources and the hollowing out of villages (Liu, 2018). Population stability is critical to sustainable rural development. Hence, the strategy for retaining labor force has become the key for rural development. Residence and employment are important elements of regional spatial structure (Zheng et al., 2006). Rural households' residential and employment location choice therefore becomes the most important spatial behavior. Farmers, as rational human being, tend to improve the economic efficiency of their families by changing their residence and working place. Rural revitalization has received extensive attention in recent years, but the human behavior embedded in this process is rarely considered. Scholars have long proposed that the development of rural industries will reduce the mobility of farmers to the city (Liang et al., 2002). However, little research has been done on rural residential and employment decisions. It is not clear how the objective living and employment conditions of farmers affect their subjective spatial behavior patterns of residential and employment choice.

A rural settlement is a type of rural locality where rural residents live and engage in producing (Yang et al., 2015). Developing local advantageous industries, providing well equipped electric power and other infrastructure, increasing the rural highways supply, as well as constructing supporting policies and systems are help to increase farmers' income and narrow the its gap (Weng et al., 2021). Symbiotic development of housing and industry can effectively resolve the problem of unemployment in rural areas and strengthen the social and economic fabric of these areas, providing a foundation for sustainable rural development and revitalization (Cheng et al., 2019). Holmes argued that multifunctionality is the central dynamic driving rural changes, not only in Australia but more generally in affluent societies (Holmes, 2006). However, the objective living and work conditions in rural areas have undergone great changes, but few scholars have taken it seriously, especially the working conditions in rural areas. It is of great significance for the sustainable development of rural areas and the formulation of government policies to clarify the influence of rural objective environment on the subjective behavior pattern of farmers.

Indicators to measure the objective suitability of living facilities(SLF) and the objective suitability of work facilities(SWF) are not unified. Thus, this article intends to sort out the concept and connotation of rural SLF and SWF, through putting forward theoretical framework and indicator system for the evaluation of SLF and SWF. These studies can help develop strategies to attract the young and educated to rural areas and to tailor local and regional devel- 
opment strategies more effectively. Through the analysis of cou-

pling coordination degree, we comprehensively evaluated the comprehensive development of rural areas in our study area. In general, the paper may have three contributions. Firstly, we put forward a theoretical framework and indicator systems to evaluate the rural development status and explore the spatial characteristics of SLF and SWF at the village level. Second, we combined the objective conditions of rural areas and the subjective choices of farmers to explore the internal logic between them. Finally, we deeply analyzed the income of farmers under different spatial behavior patterns, so as to recognize the incentives to attract labor force to stay in the countryside for the achievement of rural revitalization and sustainable development.

\section{Literature review and theoretical frame- work}

\subsection{SLF and SWF}

Livable level is an important indicator for measuring regional sustainable development. Many scholars put forward it to measure SLF since directly reflects people's quality of life in a given area (Yi et al., 2021). In general, livability consists of two core concepts: one is the high quality of life in terms of opportunities and achievements; the other is the good external and internal environments that influence the resident's life directly ( $\mathrm{Li}$ et al., 2020).

In recent decades, sustainability and livability are pursued in urban context throughout the world. Onnom et al. (2018) used the analytic hierarchy process method in establishing a livable city index for medium-class cities of a developing country and generated a map based on multiple factors that showcased the livable ones. In addition to using the AHP to develop an importance-based hierarchy of criteria, mathematical analysis was applied to derive the livability index (Mushtaha et al., 2020). Liu et al. (2020) proposed a combined subjectiveobjective way to establish an evaluation index system evaluate urban livability supported by traditional Geo-data and social media data. Based on large-scale questionnaire surveys conducted in 2015 in 40 major cities in China, Zhan et al. (2018) explored the characteristics of satisfaction with urban livability and the effect magnitude of its determinants using the geographical detector model.

All of the above literatures are about urban SLF research. However, the research on rural SLF is still relatively rare. Compared with the widespread concerns about urban livability, the concept of livability was introduced in rural studies during the 1950s against modernization and urbanization. Recently, Wang et al. (2019) evaluate the characteristics of the satisfaction levels of rural livability based on field questionnaire survey results, as well as examine the intensity effects of the related determinants, using a structural equation model (SEM). Overall, further studies are needed to provide theoretical support and practical reference for the rural human settlement environment improvement and rural revitalization in the new era.

The objective employment conditions in rural areas have attracted few attentions. Some of the abovementioned scholars have integrated the rural production function into the study of rural livability. Nevertheless, the multifunctional attributes of rural settlements and rural land use has attracted the attention of some scholars. Qu established an index system to evaluate the multifunction of rural settlements and identified the spatial distribution of ecological function, living function and production function in study area (Qu et al., 2017). Yang explored the spatial-temporal characteristics of both the coupling and coordinating relationship of the rural production-living-ecological function from 2000 to 2015 in Beijing-Tianjin-Hebei region (Yang et al., 2020).

In general, the research on rural SLF and SWF in China is still in progress, and further research is needed to provide theoretical support and practical reference for the improvement of rural living environment and rural revitalization strategy in the new era. In order to reflect the real expectations of rural residents for their living environment, a scientific rural SLF and SWF evaluation framework is needed.

\subsection{Households' spatial behavior patterns}

In the past four decades, the gap between urban and rural areas has gradually widened due to China's long-term implementation of the strategy of giving priority to industry and cities (Li et al., 2020). While urbanization and industrialization is associated with larger urban-rural income gap (Yuan et al., 2020), the rural labor force is moving to the cities in large numbers, especially in first-tier cities, such as Beijing, Shanghai, Shenzhen and Guangzhou (Zhou, 2014). In the process of citizenization, migrant workers begin to divide, while different sub-groups of migrant workers have great differences in terms of their economic activities, social integration, so do their demands and evolve progress for citizenization. As they move into cities, more and more rural residents are making trade-offs between cities and the rural areas in terms of residence and employment. The concept of semiurbanization was put forward to analyze the unbalanced integration of rural floating population in cities. According to different choices of residence and employment, rural-urban migrants can be differentiated into four types, which we call new citizens, entrepreneurs, floating population and swing group respectively (Figure 1). 


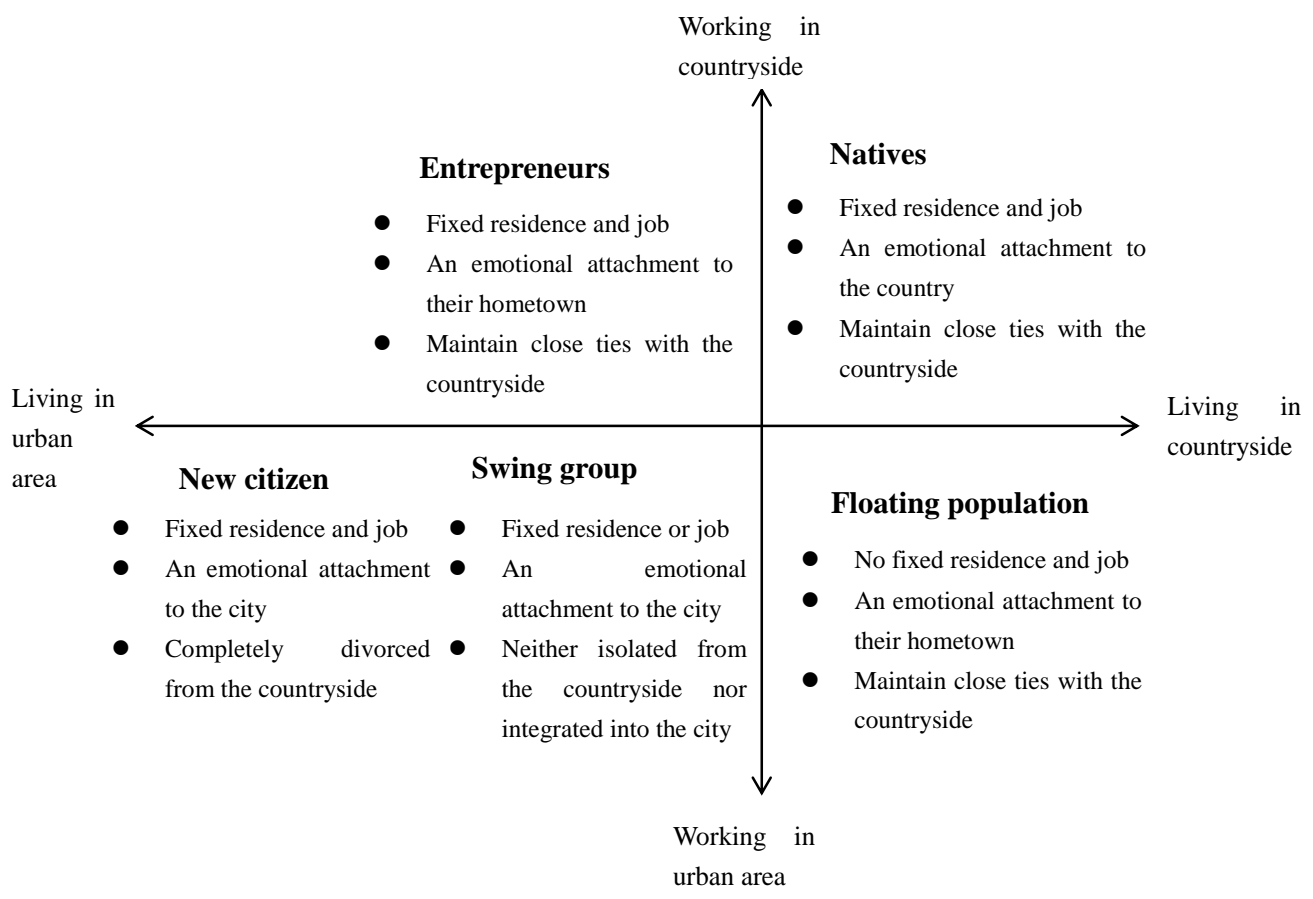

Figure 1. Household classification and its characteristics

First of all, the first type of migrant workers (new citizens) refers to those who have entirely completed the transformation from farmers to citizens, leaving the countryside and merging into the cities. Specifically, new citizens have been acquired higher levels of education and job skills, stable jobs and higher wages, higher labor market status and better economic opportunities and achievements (Tan et al., 2017). Their family has been reunited in the city and has gained equal access to social opportunities such as housing, social security, and health care, as well as their children's education. At the same time, They have extensive social networks and social connections in the city (Cao et al., 2014), showing attachment to urban society and sociocultural attachment (Chen and Liu, 2016). They also have culturally accepted the urban industrial lifestyle and psychologically consider themselves as members of cities.

The second group of migrant workers (Entrepreneurs) also settle down in cities and becomes new citizens. Different from the first group, because of the connection with the countryside, they tend to use their accumulated capital and technology to start their own business back home. Compared with traditional farmers, their human capital level is more advanced: more abundant knowledge stock, more advanced ideas and more innovative management ability. Entrepreneurs have become particularly promising for the rural population, bringing new thought to the rural lifestyle (Mattsson and Cassel, 2020).

The third type of migrant workers (Floating population) just goes to the cities to find jobs, leaving their families in the countryside. As for the temporary residents, some of them migrate only to earn enough money to accumulate capital for investment in their hometown or supplement their family budgets (Owusu, 1998). They go to cities for work but not end up settling down in cities (Tao et al., 2015). For unskilled migrant workers, the majority of which has no formal qualifications required for city residency, leaving them largely without access to social security and health benefits ( $\mathrm{Wu}$ et al., 2019). Most migrant workers cannot afford the high housing prices in cities. They still maintain an emotional attachment to countryside and a social rejection of the city ( $\mathrm{Li}$ and Rose, 2017).

The fourth category of migrant workers (Swing group) is a transitional group, lying between the first and the third. The swing group comes from the process that migrant workers increasingly break away from the countryside and fail to integrate into the city. Unlike new citizens and floating population, they may have stable residences or jobs, but they have been lost the attachment and belonging of migrant workers to their hometown, they have not obtained the household registration status of settling down in the cities as migrant workers.

In this paper, we regarded Natives as the rural residence-employment pattern. Since Swing Group, Floating Population and Entrepreneurs have inconsistent choices of in terms of residence and employment place, we classified them as urban-rural amphibious pattern. New citizens have already out of the countryside, so we regarded them as the urban residence-employment pattern. 


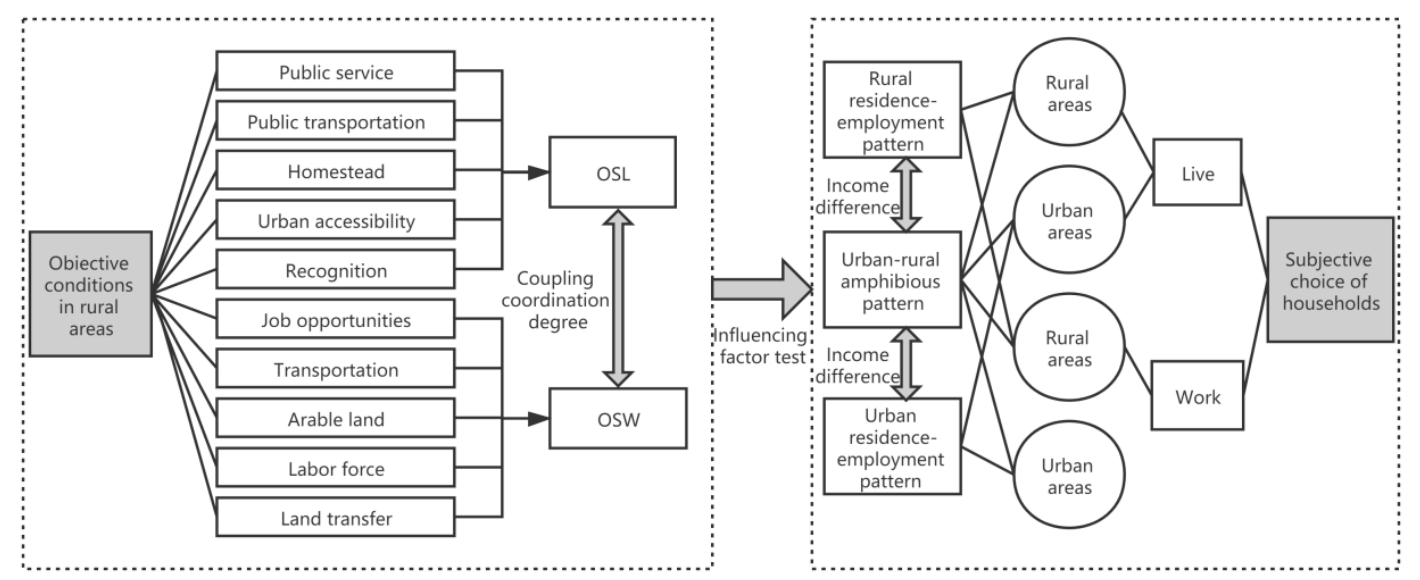

Figure 2. Research frame diagram

\subsection{Theoretical framework}

Villages are the basic economic and social elements in rural areas of China, and also the carrier of rural residents' production and living space. However, the suitability of villages has not received widespread attention. There is currently still no unified definition and measurement strategy for SLF and SWF in the available literature. It was considered that livable

countryside areas which would be suitable for residents to live would include a unity of graceful villages, beautiful environments, pleasant lifestyles, and harmonious societies (Liu et al., 2016). This paper established the evaluation system of SLF based on the national standards of Evaluation for the construction of beautiful villages (GB/T 370722018), the guidelines of rural revitalization strategy, as well as previous research findings regarding livability or the assessment of rural living conditions (Huang and Du, 2015; Wang et al., 2017). Since there are few studies on the evaluation of SWF, we select indicators according to the actual situation of the study area and study on land use multifunctional (Zhou et al., 2017; Zou et al., 2021). SLF and SWF are objective measures of the countryside. In fact, farmers have a variety of choices when choosing a place of residence and employment. The diversity of employment and residence leads to spatial mismatch. The concept of jobshousing balance was developed by scholars in urban studies (Li and Liu, 2016). Although the choices of residence and employment are independent, the two choices interact with each other, and considering one aspect in isolation may lead to bias. While existing theories and intuitions support bidirectional interactions between employment and residence, Steinnes (1978) uses two-stage least square method (TSLS) to build the residential location model and the employment location model respectively. Studies have concluded that the location of population and the location of work were determined simultaneously (Kimaro et al., 2015). Therefore, we comprehensively considered the housing and employment choices of farmers and divide them into three spatial behavior patterns.

Modern push-pull theory holds that in addition to income, migration is pushed and pulled by infrastructure conditions, such as medical facilities, educational facilities and environmental conditions (Hare, 1999). This study is based on the theory of farmers' behavior of the school of rational peasants. First, economic rationality is the basic starting point for farmers' decision-making behavior. In addition, the new migration economic theory proposes that family decision-making is not completely determined by individuals, but more by families. Therefore, in this paper, we explore whether there are differences in household income under different spatial behavior patterns.

\section{Materials and Methods}

\subsection{Study area}

Poyang Lake basin $\left(113^{\circ} 34^{\prime} 36^{\prime \prime}-118^{\circ} 28^{\prime} 58^{\prime \prime} \mathrm{E}\right.$, $\left.24^{\circ} 29^{\prime} 14^{\prime \prime}-30^{\circ} 04^{\prime} 41^{\prime \prime} \mathrm{N}\right)$ is located in the Jiangxi province, southeast of China. With Ganjiang River running through the whole Poyang Lake basin, it has abundant agricultural resources and obvious ecological advantages, with 3,082.21 thousand hectares arable area at the end of 2016. There also have a large agricultural population, a large rural area and a relatively high proportion of agriculture. The urbanization rate of resident population is $57.4 \%$, which is lower than the national average rate $60.60 \%$. In 2019, Poyang Lake basin's GDP was 2.47575 trillion yuan. The outflow of massive labor force in the rural areas of Poyang Lake basin has become a serious problem. There were 12.066 million urban employees, accounting for $45.8 \%$ of the total labor force in study area. Meanwhile, there were 9.086 million rural migrant workers. Among them, 5.990 million were went outside the province, increased by 1.5 percent compared to the previous year, while 3.096 million stayed in Poyang Lake basin, increased by 3.4 percent. With large rural areas, ample arable land and massive migrate 


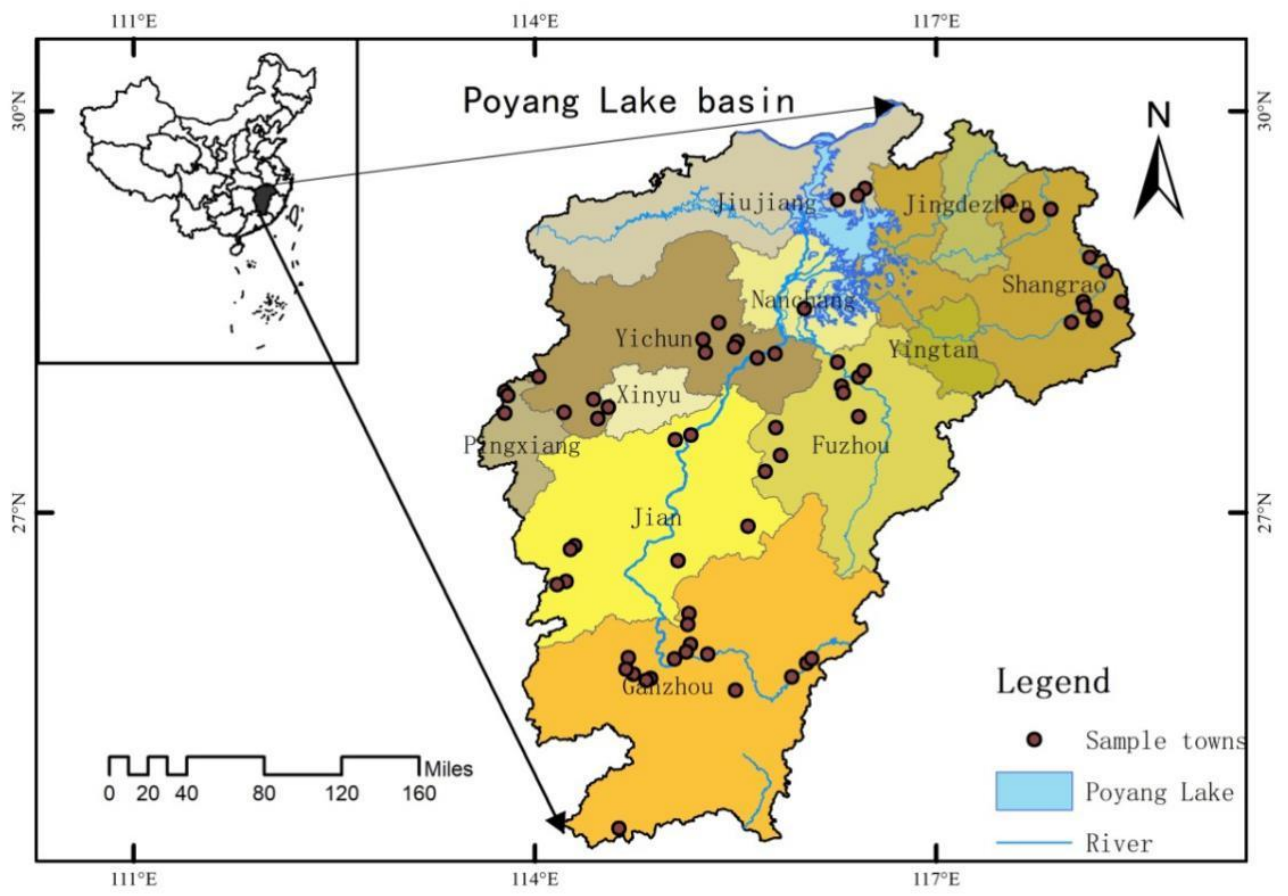

Figure 3. Study area

Table 1. Indices for the evaluation of SLF and SWF

\begin{tabular}{|c|c|c|c|c|}
\hline \multicolumn{2}{|c|}{ Index } & Explanation & Weight & Attribute \\
\hline \multirow{5}{*}{ SLF } & Public service & $\begin{array}{c}\text { Basic education, medical facilities and sanitation } \\
\text { were added with the equal weight after standardi- } \\
\text { zation }\end{array}$ & 0.147 & + \\
\hline & Public transportation & Does the village have public transport & 0.395 & + \\
\hline & Homestead & Homestead area per capita & 0.130 & + \\
\hline & Urban accessibility & $\begin{array}{c}\text { The distance from the village to the nearest town } \\
\text { center }\end{array}$ & 0.155 & - \\
\hline & Recognition & $\begin{array}{l}\text { The average recognition degree of villagers to the } \\
\text { development prospect of the village }\end{array}$ & 0.173 & + \\
\hline \multirow{5}{*}{ SWF } & Job opportunities & $\begin{array}{l}\text { The number of primary, secondary and tertiary } \\
\text { industries were added with the equal weight after } \\
\text { standardization }\end{array}$ & 0.166 & + \\
\hline & Transportation & Accessibility to roads & 0.234 & + \\
\hline & Arable land & Arable land per capita & 0.090 & + \\
\hline & Labor force & Proportion of migrant workers in village & 0.245 & - \\
\hline & Land transfer & Proportion of land circulation in villages & 0.265 & + \\
\hline
\end{tabular}

workers, Poyang Lake basin is typically to analysis the rural basic situation and spatial behavior pattern of farmers. There are a total of 100 county-level administrative regions in the Poyang Lake basin, of which 24 were surveyed by us.

\subsection{Data}

The data used in this study are from a field survey in Poyang Lake basin of China, January 2020. It's a cross-sectional survey, covering 24 counties, districts and prefecture-level cities with a simple random sampling. The objects of our survey are rural population over 18 years old with working capability who have a rural residence. For each county, three levels of sampling towns were defined according to their feature: suburban town, remote town and characteristic town. After dealing with the outliers, 839 valid questionnaires from 123 villages were obtained. For each village, we conducted field research on its location, economic and industrial conditions and the configuration of the infrastructure. For each respondent, information was gathered on their characteristics such as age, gender, employment and residential choice, perception of policy and so on.

\subsection{Methods}

Because the measurement units and orders of magnitude of the indicators that measure rural SLF and SWF are different, and each indicator has a positive or negative impact on the system. Therefore, each indicator needs to be standardized before all calculations. $x_{i}$ represent the indicators in Table 1 . The standardized calculation formula of positive indica- 
tors $x_{i}^{+}$and negative indicators $x_{i}^{-}$we adopted is as follows:

$\begin{aligned} \mathrm{x}_{i}^{+} & =\frac{x_{i}-\min \left(x_{i}\right)}{\max \left(x_{i}\right)-\min \left(x_{i}\right)} \\ x_{i}^{-} & =\frac{\max \left(x_{i}\right)-x_{i}}{\max \left(x_{i}\right)-\min \left(x_{i}\right)}\end{aligned}$

\subsubsection{CRITIC method}

CRITIC method, first proposed by Diakoulaki et al. (1995), is an objective weighting method that determines the weight according to the contrast intensity and conflict of indicators. Among them, contrast intensity refers to the value difference in evaluation index, which is measured by standard deviation $e_{j}$. The conflict between the indicator $\mathrm{j}$ and other indicators is calculated as $\sum_{i=1}^{n}\left(1-\mathrm{r}_{i j}\right)$, and $\mathrm{r}_{i j}$ is the correlation coefficient between indicator $\mathrm{i}$ and $\mathrm{j}$. The information contained in index $\mathrm{j}$ is determined by the product of the standard deviation of the evaluation indicator and the degree of conflict, shows as Eq. (3).

$\mathrm{I}_{\mathrm{j}}=\mathrm{e}_{\mathrm{j}} \sum_{\mathrm{i}=1}^{\mathrm{n}}\left(1-\mathrm{r}_{i j}\right)$

$w_{j}=\frac{I_{j}}{\sum_{j=1}^{m} I_{j}}$

$w_{j}$ is the objective weight of the indicator $\mathrm{j}$, which can be obtained from Eq. (4).

\subsubsection{Coupling coordination degree model}

Based on the evaluation of SLF and SWF, the coupling coordination degree model is used to calculate the coupling coordination degree of living and employment conditions of each village.

$\mathrm{C}=\left(\frac{\mathrm{SLF} * \mathrm{SWF}}{\mathrm{SLF}+\mathrm{SWF}}\right)^{1 / 2}$

$\mathrm{C}$ is the coupling degree reflecting the interaction and influence between SLF and SWF of villages. T is the comprehensive coordination index between SLF and SWF (see Eq. (7)). Both $\alpha$ and $\beta$ are constants which $\alpha+\beta=1$. In this study, both $\alpha$ and $\beta$ are set as 0.5 . The coupling coordination degree $\mathrm{D}$ can comprehensively reflect the interaction and coordination degree between systems, which can be obtained from Eq. (6).

$\mathrm{D}=\sqrt{C * T}$

$\mathrm{T}=\alpha U_{1}+\beta U_{2}$

\subsubsection{Multinomial logit model (MNL)}

We divided the behavior pattern into three types according to the different combination of employment place and residence place of peasant households. One is to live and work in the countryside, and the second is to live and work in the city. Both of these two patterns reflect the integration of household and employment. The third is the urbanrural amphibious pattern, which reflects the semiurbanization of peasant households, including urban residence-rural employment and rural residenceurban employment.

In the ordered model, the influence of variables increases the probability of the most severe re- sponse type and decreases the probability of the least severe response type (Geedipally et al., 2011). Therefore, ordered logit can be empirically biased. The multinomial logit model is an extension of the binary logit model, which is used when the dependent variable has several categories that are unordered. The MNL model used in this study is as follows.

$Y_{i}=\alpha_{m}+\sum_{k=1}^{k} \beta_{m k} X_{i k}+u_{i}$

$Y_{i}$ is multi-classification variable of household spatial behavior pattern. $X$ is a vector of individual characteristics of farmers and SLF and SWF that affect spatial behavior pattern. $\beta_{m k}$ is the parameter to be estimated and $\mathrm{K}$ is the error term. In this paper, the reference is set as $\mathrm{M}$, and the value of other types of spatial behavior pattern is $\mathrm{m}=1, \ldots, \mathrm{M}-1$. Therefore, the Logit model can be expressed as:

$\ln \frac{\operatorname{prob}\left(Y_{i}=m\right)}{\operatorname{prob}\left(Y_{i}=M\right)}=\alpha_{m}+\sum_{k=1}^{K} \beta_{m k} X_{i k}=Z_{m i}$

Where, $Y_{i}=M$ represents the reference and $Y_{i}=m$ represents the other items. For reference, the multinomial logit model is estimated according to Eq. 10. For other items, the multinomial logit model is estimated according to Eq. 11.

$\operatorname{prob}\left(Y_{i}=\mathrm{M}\right)=\frac{1}{1+\sum_{h=1}^{m-1} \exp \left(Z_{h i}\right)}$
$\operatorname{prob}\left(Y_{i}=\mathrm{m}\right)=\frac{\exp \left(Z_{m i}\right)}{1+\sum_{h=1}^{m-1} \exp \left(Z_{h i}\right)}$

\subsubsection{Quantile regression}

Classical OLS regression model, through the conditional expectation $\mathrm{E}(y \mid x)$, calculate the influence of the independent variable $\mathrm{x}$ on the dependent variable y. Classical OLS regression is represented by the following formula:

$y=\beta x+\varepsilon$

Among them, $\beta$ is the regression coefficient, and $\varepsilon$ is the error term. The classical OLS regression only pays attention to the conditional mean of the dependent variable but does not fully consider the complete characteristics and skewed distribution of the conditional distribution of the dependent variable. Therefore, it may lead to errors in estimation results. The quantile regression method can be used to get regression of explanatory variables with explained variables under different quantiles to obtain the influence of the explanatory variables on the whole conditional distribution. The general form of quantile regression model is represented as follows:

$y_{i}=x_{i}^{\prime} \beta_{\theta}+\mu_{\theta i}, 0<\theta<1$

Quant $_{\theta}\left(y_{i} \mid x_{i}\right)=x_{i} \beta_{\theta}$

where $\mathrm{x}$ is the vector of independent variables and $\mathrm{y}$ is the explained variable. $\theta$ represents the quantile point, and $\mu$ is the random disturbance term. $\beta_{\theta}$ indicates the $\theta$ quantile regression coefficient to be estimated. The estimator $\hat{\beta}$ is obtained by the following minimization objective function: $\min \sum_{y_{i} \geq x_{i}^{\prime} \beta} \theta\left|y_{i}-x_{i}^{\prime} \beta\right|+\sum_{y_{i}<x_{i}^{\prime} \beta}(1-$ $\theta)\left|y_{i}-x_{i}^{\prime} \beta\right|$ 
Table 2. Variable definition and data description of sample villages and interviewees

\begin{tabular}{|c|c|c|c|}
\hline Index & Explanation & Mean & S.D. \\
\hline \multicolumn{4}{|c|}{ Village characteristics } \\
\hline Basic educational facilities & The actual number of schools & 2.29 & 1.66 \\
\hline Medical facilities & The actual number of clinics or pharmacies & 2.99 & 4.05 \\
\hline $\begin{array}{l}\text { Environmental sanita- } \\
\text { tion }\end{array}$ & The actual number of cleaners & 3.49 & 3.97 \\
\hline Public transportation & Does the village have public transport: $\mathrm{No}=0, \mathrm{Yes}=1$ & 0.23 & .42 \\
\hline Homestead & Homestead area per capita $\left(\mathrm{m}^{2}\right)$ & 28.79 & 10.31 \\
\hline Urban accessibility & $\begin{array}{l}\text { The distance from the village to the nearest town center } \\
\qquad(\mathrm{m})\end{array}$ & 5.67 & 6.52 \\
\hline Recognition & $\begin{array}{l}\text { The average recognition degree of villagers to the devel- } \\
\text { opment prospect of the village: poor }=1 \text {, general }=2 \text {, promising } \\
=3\end{array}$ & 2.67 & 0.34 \\
\hline The primary industry & $\begin{array}{l}\text { The number of enterprises in the primary industry: } 0=1 ; 1 \text { - } \\
2=2 ; \text { more than } 2\end{array}$ & 1.35 & 0.55 \\
\hline The secondary industry & $\begin{array}{l}\text { The number of secondary enterprises in the secondary in- } \\
\text { dustry: } 0=1 ; 1-2=2 ; \text { more than } 2\end{array}$ & 1.49 & 0.74 \\
\hline The tertiary industry & $\begin{array}{l}\text { The number of tertiary enterprises in the secondary indus- } \\
\text { try: } 0=1 ; 1-2=2 ; \text { more than } 2=3\end{array}$ & 1.25 & 0.50 \\
\hline Transportation & $\begin{array}{r}\text { The type of road closest to the village: none }=0 \text {, county } \\
\text { highway }=1 \text {; provincial highway }=2 \text {; national highway }=3 \text {; ex- } \\
\text { pressway }=4\end{array}$ & 2.10 & 1.38 \\
\hline Arable land & Arable land per capita $\left(\mathrm{m}^{2}\right)$ & 451.43 & 33.63 \\
\hline \multicolumn{4}{|c|}{ Individual characteristics } \\
\hline Labor force & $\begin{array}{l}\text { Proportion of migrant workers in village: } 70 \% \text { above }=1 \text {, } \\
30 \%-70 \%=2 \text {, more than } 30 \%=3\end{array}$ & 1.85 & 0.72 \\
\hline Land transfer & $\begin{array}{l}\text { Proportion of land circulation in villages: } 0-30 \%=1,30 \%- \\
\qquad 60 \%=2 \text {, more than } 60 \%=3\end{array}$ & 1.56 & 0.78 \\
\hline Gender & Female $=0$, Male $=1$ & 0.71 & 0.46 \\
\hline Age & Actual age & 46.79 & 12.90 \\
\hline Household income & Family's income in 2019 (Ten thousand Yuan) & 10.71 & 14.80 \\
\hline Educational level & $\begin{array}{l}\text { Junior high school or below }=0 \text {; High School or Junior col- } \\
\text { lege }=1 ; \text { College or above }=2\end{array}$ & 0.37 & 0.58 \\
\hline Labor force & The ratio of the labor force to the total number of family & 0.61 & 0.21 \\
\hline
\end{tabular}

Table 3. Distribution of SLF and SWF

\begin{tabular}{|c|c|c|c|c|c|}
\hline Proportion (\%) & lower-level & low-level & middle-level & high-level & higher-level \\
\hline SLF & 14.63 & 56.09 & 6.50 & 4.89 & 17.89 \\
\hline SWF & 20.33 & 36.59 & 32.52 & 9.76 & 0.81 \\
\hline
\end{tabular}

\section{Results and discussions}

\subsection{Descriptive analysis}

4.1.1. Descriptive analysis of sample villages

Table 2 presents the basic profiles of sample villages. As can be seen from the standard deviations of rural infrastructure, there is a large degree of dispersion of medical facilities and environmental sanitation among the sample villages. In addition, only $23 \%$ of villages have access to public transport. The average population of migrant workers in sample villages exceeds $70 \%$, which fully shows the current situation of hollowing out and aging weakening of rural areas. Although most of the labor force has chosen to leave the countryside to work in the cities, a majority of villages are considered to have a promising development prospect. The proportion of rural land transfer is low, which indicates that the high idle rate of rural land and the low utilization rate. The per capita homestead area is $28.84 \mathrm{~m}^{2}$ and the per capita cultivated land area is $446.67 \mathrm{~m}^{2}$.

\subsubsection{Descriptive analysis of interviewees}

Table 2 also shows the basic profiles of respondents. It shows that the majority of respondents were men with a junior high school degree or below. The average age is 46.76 years old and the average family income of the entire sample is 17100 yuan. On average, the labor force in the households of respondents was 60 percent of the total population.

\subsection{Characteristics of SLF and SWF}

\subsubsection{Evaluation of $S L F$ and $S W F$}

Taking the administrative village as the evaluation unit, we estimated the SLF and SWF values of 123 villages in Poyang Lake basin by using CRITIC method based on the indexes in Table 1. The calculation results were again normalized so that the final results fell within the range [0-1]. We used an equal interval method to further classify the SLF and SWF of villages into five categories: lowerlevel [0-0.2), low-level [0.2-0.4), middle-level [0.40.6), high level [0.6-0.8), higher-level [0.8-1]. 
Table 4. Distribution of coupling coordination degree

\begin{tabular}{|c|c|c|}
\hline Classes & Range & Proportion (\%) \\
\hline Low-level coupling & {$[0-0.3)$} & 3.25 \\
\hline Antagonism stage & {$[0.3-0.5)$} & 22.76 \\
\hline Adaptive stage & {$[0.5-0.7)$} & 52.85 \\
\hline High-level coupling & {$[0.7-1]$} & 21.14 \\
\hline
\end{tabular}

Table 5. Regional heterogeneity analysis

\begin{tabular}{|c|c|c|c|c|c|c|}
\hline \multirow{2}{*}{ Regional types } & \multicolumn{2}{|c|}{ Remote towns } & \multicolumn{2}{c|}{ Sub-urban towns } & \multicolumn{2}{c|}{ Characteristic towns } \\
\cline { 2 - 7 } & $\begin{array}{c}\text { Remote } \\
\text { villages }\end{array}$ & $\begin{array}{c}\text { Sub-urban } \\
\text { villages }\end{array}$ & $\begin{array}{c}\text { Remote } \\
\text { villages }\end{array}$ & $\begin{array}{c}\text { Sub-urban } \\
\text { villages }\end{array}$ & $\begin{array}{c}\text { Remote } \\
\text { villages }\end{array}$ & $\begin{array}{c}\text { Sub-urban } \\
\text { villages }\end{array}$ \\
\hline SLF & 1.85 & 2.11 & 2.91 & 3.17 & 1.78 & 2.68 \\
\hline SWF & 2.23 & 2.11 & 2.36 & 2.38 & 3.00 & 2.36 \\
\hline Coupling coordination degree & 2.62 & 2.79 & 2.91 & 3.14 & 2.89 & 3.00 \\
\hline
\end{tabular}

Table 6. Results of the multinomial logit regression

\begin{tabular}{|c|c|c|}
\hline \multirow{2}{*}{ Explanatory variable } & Rural residence-employment pattern & Urban-rural amphibious pattern \\
\hline & Coefficient & Coefficient \\
\hline Gender & $-0.542^{* *}$ & 0.188 \\
\hline Age & $0.085^{* * *}$ & $0.042^{* * *}$ \\
\hline Education & -0.222 & $-0.750^{* *}$ \\
\hline Annual household income & $-1.083^{* * *}$ & 0.003 \\
\hline Household labor ratio & 0.068 & 0.146 \\
\hline SLF & $0.733^{*}$ & $1.649^{* * *}$ \\
\hline SWF & 0.077 & $1.282^{*}$ \\
\hline Constant & $-1.152^{*}$ & $-3.739^{* * *}$ \\
\hline Pseudo $R^{2}$ & \multicolumn{2}{|c|}{$\frac{1}{0.1855}$} \\
\hline Prob $>$ chi 2 & \multicolumn{2}{|c|}{0.000} \\
\hline
\end{tabular}

As shown in Table 3, majority of villages in Poyang lake basin attained a low-level SLF, accounting for $56.1 \%$ of all sample villages. The lower-level SLF and higher-level SLF of villages had similar proportions, 14.6 percent and 17.9 percent respectively. In addition, the proportion of villages at the middle-level SLF and high-level SLF was just $6.5 \%$ and $4.95 \%$. Overall, the SLF of villages in Poyang lake basin was not high. As for SWF, the low-level of SWF of villages has the maximal proportion $36.6 \%$, while the higher-level SWF only accounts for $0.8 \%$. The mean difference between SLF and SWF was not significant. However, there is a large gap between SLF and SWF at a higher level. In general, rural SWF lags behind SLF.

\subsubsection{Coupling coordination degree}

We put SLF and SWF into the coupling coordination degree model, and obtained the coupling coordination degree of 123 villages. There is no unified standard for the classification of coupling coordination degree, and we divided the coupling coordination degree into four levels (Table 4). More than half of the villages are in the stage of adaptation. The villages with high level of coupling accounted for $21.1 \%$. Overall, the level of coordination between SLF and SWF is high, but still needs to be improved.

However, the majority of rural areas are in the adaptation stage, which makes the average level of coupling coordination degree reflect limited infor- mation. SLF and SWF of different levels were set as 1 to 5 and coupling coordination degree of different levels was set as 1 to 4 to further analyze their regional heterogeneity (Table 5). SLF in suburban towns are higher than other towns, both in remote and suburban rural areas. And suburban villages generally have better SLF than remote villages. As for SWF, it shows completely different characteristics from SLF. It is apparent from this result that higher SWF values appeared in characteristic towns and sub-urban towns. On the one hand, the strong support of the government to the characteristic towns provides a lot of funds and employment opportunities, which improves the SWF. On the other hand, due to the expansion of urbanization, a large number of suburban farmland has been occupied, which is conducive to the development of industry. For different types of rural areas, the level of coupling coordination degree in suburban rural areas is always higher than that in remote rural areas. This indicates that SWF and SLF are more coordinated in suburban rural areas. The regions with higher coupling coordination degree are basically consistent with the regions with higher SLF.

\subsection{Determinants to households' spatial behav- ior pattern}

Through the field survey questionnaire, we obtained a total of 839 valid questionnaires from 123 villages after removing the outliers, showing the 
Table 7. Results of the quantile regression of family income

\begin{tabular}{|c|c|c|c|c|c|c|}
\hline \multirow{2}{*}{ Explanatory variable } & \multirow{2}{*}{ OLS } & \multicolumn{5}{|c|}{ Quantile regression } \\
\hline & & 10th & 25 th & 50th & 75th & 90th \\
\hline Gender & 0.029 & -0.183 & -0.119 & 0.160 & 0.019 & 0.142 \\
\hline Age & -0.001 & -0.001 & $0.007^{*}$ & 0.004 & $0.009^{* *}$ & $0.012^{* *}$ \\
\hline Education & $0.239^{* *}$ & $0.212^{*}$ & $0.260^{* *}$ & $0.158^{* * *}$ & $0.189^{*}$ & $0.205^{* * *}$ \\
\hline Household labor ratio & $0.763^{* * *}$ & 0.400 & $0.178^{* *}$ & $0.667^{* * *}$ & $0.729^{* * *}$ & $0.827^{* * *}$ \\
\hline \multicolumn{7}{|l|}{ Spatial behavior pattern } \\
\hline Rural residence-employment pattern & $-0.443^{* * *}$ & $-0.100^{* * *}$ & $-0.572^{* * * *}$ & $-0.428^{* * *}$ & $-0.458^{* * *}$ & $0.560^{* * *}$ \\
\hline Urban-rural amphibious pattern & 0.196 & 0.198 & -0.150 & -0.029 & -0.081 & -0.116 \\
\hline \multicolumn{7}{|l|}{ Urban residence-employment pattern (=ref.) } \\
\hline Constant & $1.429^{* * *}$ & 0.550 & $0.688^{* * *}$ & $1.205^{* * *}$ & $1.292^{* * *}$ & $1.363^{* * *}$ \\
\hline $\mathrm{R}^{2}$ & \multicolumn{6}{|c|}{0.888} \\
\hline $\mathrm{F}$ & \multicolumn{6}{|c|}{$13.40^{* * *}$} \\
\hline
\end{tabular}

respondents' objective preferences for residence and employment. In order to explore the impact of objective housing and employment environment on farmers' subjective housing and employment behavior, we used the multinomial logit model. Tables 6 show the results.

Since we focused on the relationship and sustainable development between SLF and SWF in rural areas, we used urban residence-employment pattern as a reference. First of all, compared with the urban residential-employment pattern, people with rural residence-employment pattern are characterized by male and a higher age, which is the same as the previous conclusion. This is also consistent with the current situation that a large number of young and middle-aged rural labor forces migrate leading to the formation of hollowed villages. The income of farmers in the rural residence-employment pattern is significantly less than that in the urban residenceemployment pattern. In addition, higher SLF is beneficial for farmers to choose rural residenceemployment pattern, while SWF was not statistically significant. Higher SLF in rural areas is conducive to attracting farmers to stay and work in rural areas. It's worth emphasizing that the regression result was obtained by removing two outliers of extremely high income. They account for only $0.36 \%$ of the total sample, but 65 times the average income of the total sample, and 91 times that of farmers who also belong to the rural residence-employment pattern. They are in the highest income brackets among respondents engaged in non-farm activities. This shows that the vast, cheap and promising land of the countryside has made their careers and brought them great wealth. Besides, both of them started businesses in rural areas with higher SWF. As for farmers with rural-urban amphibious pattern, they also have higher ages and lower levels of education. Annual household income is not statistically significant. This indicates that the income gap between rural-urban amphibious pattern and urban residence-employment pattern is not large. As expected, the SLF and SWF are significantly positive, which means higher SLF and SWF can encourage people to choose urban-rural amphibious pattern.
For farmers living in the suburban areas and working in the city, better objective living conditions provide them with low housing costs. They can not only save living expenses, but also get a higher salary by working in the city with convenient transportation.

\subsection{The family income gap of farmers under different spatial behavior patterns}

In order to further explore the relationship between household income and farmers' spatial behavior pattern, we used quantile regression method to further explore the influence of spatial behavior pattern on different income groups of farmers. The empirical results of OLS and quantile regression are reported in Table 7.

OLS method estimates the mean impact of peasant households' spatial behavior patterns on income, so it is not suitable to compare the income differences of households under different patterns. In order to further analyze rural household income differences under different patterns, quantile regression method used to compare the results for the 10th, 25th, 50th, 75 th and 90th quantiles. The results of OLS estimation show that the coefficients of education, household labor ratio and urban residence-employment pattern are significant. Education level and household labor ratio would have a positive effect on household income. As for spatial behavior pattern, rural households with the urban residenceemployment pattern have a higher income than those follow rural residence-employment pattern. However, the coefficient of urban-rural amphibious pattern is not statistically significant.

Empirical results show that there are differences between the parameters obtained by OLS and quantile regression. At the 10th, 75th and 90th quantiles, the low and high income percentile, age has significant positive effects on family income. Although there is still a positive correlation between education level and income in each quantiles, it is not difficult to find that the influence of education level on different income groups fluctuates. With the increase of farmers' income quantile, the promoting 
effect of education level on income rises, falls and rises again. With the increase of income quantile, the positive influence of household labor ratio on household income is greater.

However, rural residence-employment pattern has a significant positive effect on household income in each quantile, but the urban-rural amphibious pattern is not statically significant. It proved that there is no significant difference in the family income between urban-rural amphibious pattern and urban residence-employment pattern in each quantile. However, the rural residence-employment pattern effects were slighter in the lower quantiles than in the upper quantiles. The large income gap between urban and rural areas is a major problem in China's economic development.

\section{Conclusions}

Although regional livability in China has attracted more and more attention from the public and the government in recent years, previous studies have mainly focused on the evaluation of urban livability. Despite the large amount, low cost of land and labor in the countryside, the productive function in the countryside is always neglected, and the work facilities in the countryside are rarely evaluated in the existing literature. Based on the field survey of 123 villages in Poyang Lake basin, we evaluated the objective conditions of the sample villages, SLF and SWF, based on village level data. Then, we verify the effect of objective environment on farmers' subjective spatial behavior patterns of residence and employment. Finally, the quartile regression method is used to further examine the income differences of farmers under different spatial behavior patterns. The main conclusions are as follows.

The average SLF and SWF were 2.55 and 2.34 respectively. Although the mean values of SLF and SWF are similar, SLF is mostly distributed at a higher level. Specifically, $17.89 \%$ of the villages had a higher-level of SLF, while only $0.81 \%$ of the sample villages had a higher-level of SWF. Therefore, more attention should be paid to taking measures to promote the development of rural industries to change the situation of the lagging development level of rural industries. In addition, we divided villages into six categories according to different township types and the distance from village to town center, so as to identify the heterogeneity of SLF and SWF. The key findings from the analyses show that there has a higher SLF in suburban towns and suburban villages. However, the higher SWF is mostly distributed in suburban towns and characteristic towns.

SLF and SWF only evaluated the objective conditions of individual villages. The results obtained from the multinomial logit model had confirmed that the objective conditions in rural areas affect the choice of farmers' subjective spatial behavior pat- tern of residence and employment. Compared with the urban residence-employment pattern, people with rural residence-employment pattern are characterized by male, higher age and lower income. In addition, higher SLF is beneficial for farmers to choose rural residence-employment pattern, while SWF was not statistically significant. In the survey, we noticed that a small part of the rural residenceemployment model of farmers have a very high income, account for only $0.36 \%$ of the total sample, but their income is 65 times the average of the total sample, and 91 times that of farmers who also belong to the rural residence-employment pattern. Furthermore, they are all located in the higher areas of SWF. This finding was unexpected and suggests that although SWF in rural areas is not significant for the overall sample, it creates good conditions for a small number of people, which showing the huge potential for people to create wealth in the countryside. In contrast, compared with the urban residence-employment model, the rural-urban amphibious model shows higher age and lower education level, but the income was not significant. Besides, both SLF and SWF have significant promoting effects on farmers' choice of rural-urban amphibious pattern.

Rural households with the rural residenceemployment pattern have a $19.6 \%$ lower income than those follow urban residence-employment pattern. The results of quantile regression allowed us to understand that, no matter in what quantiles, the income of farmers with urban-rural amphibious pattern and urban residence-employment pattern is higher than that of rural residence-employment. The urban-rural amphibious pattern is the optimal spatial behavior pattern for both rural development and famer individuals. On the one hand, farmers can get higher income in this pattern; on the other hand, farmers in the urban-rural amphibious pattern can bring population and vitality to the countryside.

\section{Policy implication}

First, governments should be committed to improving the current serious outflow of rural labor force, pay attention to the housing and employment problems in rural areas, and improve objective living and employment conditions. In particular, the employment environment in rural areas needs to be improved.

Second, governments should make overall plans to revitalize the countryside and tailor policies to local conditions according to their advantages. Priority of development of industries should be given to suburban towns and characteristic towns and the objective living conditions in remote villages should also be further improved. Suburbs and characteristic towns can be used as rural growth poles for industrial development. Suburban towns with distinctive features should be built into rural growth poles for 
industrial development, and become the gathering points of employment in nearby rural areas. Characteristic towns should rely on their natural advantages, firstly realize urban-rural integration, and then drive the development of rural enterprises in nearby towns with characteristic towns. Make characteristic town become the engine that improves rural appearance, accelerate rural economy grows. Third, governments should further reform the rural land system and investment system and further liberalize the rural market to create a better policy environment for rural entrepreneurship. The government should encourage farmers to adopt the urban-rural amphibious spatial behavior pattern to further increase the income of farmers.

Finally, the aging of the rural population is a serious problem. As the enthusiasm of young people and farmers with higher education level to participate in agriculture is not high, governments should promote the cooperation between universities and rural areas, and set up a university student cooperation base in rural areas. For college students who want to start a business in rural areas, governments should actively provide land transfer coordination, financial support and technical services.

\section{Funding}

This research was funded by National Natural Science Foundation of China (Grant No. 71764017).

\section{References}

1. CAO G., LI M., MA Y., TAO R., 2014, Selfemployment and intention of permanent urban settlement: Evidence from a survey of migrants in China's four major urbanising areas, Urban Studies, 52(4): 639-664.

2. CHEN S., LIU Z., 2016, What determines the settlement intention of rural migrants in China? Economic incentives versus sociocultural conditions, Habitat International, 58: 42-50.

3. CHENG M., YANSUI L., ZHOU Y., 2019, Measuring the symbiotic development of rural housing and industry: A case study of Fuping County in the Taihang Mountains in China, Land Use Policy, 82: 307316.

4. DIAKOULAKI D., MAVROTAS G., PAPAYANNAKIS L., 1995, Determining objective weights in multiple criteria problems: The critic method, Computers \& Operations Research, 22(7): 763-770.

5. GEEDIPALLY S. R., TURNER P. A., PATIL S., 2011, Analysis of Motorcycle Crashes in Texas with Multinomial Logit Model, Transportation Research Record, 2265(1): 62-69.

6. HARE D., 1999, 'Push' versus 'pull' factors in migration outflows and returns: Determinants of migration status and spell duration among China's rural population, The Journal of Development Studies, 35(3): 45-72.

7. HOLMES J., 2006, Impulses towards a multifunctional transition in rural Australia: Gaps in the research agenda, Journal of Rural Studies, 22(2): 142160 .
8. HUANG Z., DU X., 2015, Assessment and determinants of residential satisfaction with public housing in Hangzhou, China, Habitat International, 47: 218230.

9. KIMARO P. J., TOWO N. N., MOSHI B. H., 2015, Determinants of Rural Youth's Participation in Agricultural Activities: The Case of Kahe Eaet Ward in Moshi Rural District,Tanzania, International Journal of Economics, Commerce and Management, 3(2): $1-47$.

10. LI J., ROSE N., 2017, Urban social exclusion and mental health of China's rural-urban migrants - A review and call for research, Health \& Place, 48: 20-30.

11. LI S., DONG Y., ZHANG L., LIU C., 2021, Offfarm employment and poverty alleviation in rural China, Journal of Integrative Agriculture, 20(4): 943- 952.

12. LI S., LIU Y., 2016, The jobs-housing relationship and commuting in Guangzhou, China: Hukou and dual structure, Journal of Transport Geography, 54: 286-294.

13. LI W., LI J., CUI J., 2020, Exploring rural decline with the perspective of demographics: Case study of Hubei, China, Physics and Chemistry of the Earth, Parts A/B/C, 120:102917.

14. LI Y., QIAO L., WANG Q., DáVID K., 2020, Towards the evaluation of rural livability in China: Theoretical framework and empirical case study, Habitat International, 105: 102241.

15. LIANG Z., CHEN Y. P., GU Y., 2002, Rural Industrialisation and Internal Migration in China, Urban Studies, 39(12): 2175-2187.

16. LIU J., BI H., WANG M., 2020, Using multi-source data to assess livability in Hong Kong at the community-based level: A combined subjectiveobjective approach, Geography and Sustainability, 1(4): 284-294.

17. LIU Y., 2018, Research on the urban-rural integration and rural revitalization in the new era in China, Acta Geographica Sinica, 73: 637-650.

18. LIU Y., LI Y., 2017, Revitalize the world's countryside, Nature, 548(7667): 275-277.

19. LIU Y., LONG H., CHEN Y., et al., 2016, Progress of research on urban-rural transformation and rural development in China in the past decade and future prospects, Journal of Geographical Sciences, 26(8): 1117-1132.

20. LONG H., WOODS M., 2011, Rural Restructuring under Globalization in Eastern Coastal China: What can we learn from Wales?, Journal of Rural and Community Development, 6: 70-94.

21. MATTSSON K. T., CASSEL S. H., 2020, Immigrant Entrepreneurs and Potentials for Path Creating Tourism Development in Rural Sweden, Tourism Planning \& Development, 17(4): 384-403.

22. MUSHTAHA E., ALSYOUF I., AL LABADI L., HAMAD R., KHATIB N., AL MUTAWA M., 2020, Application of AHP and a mathematical index to estimate livability in tourist districts: The case of $\mathrm{Al}$ Qasba in Sharjah, Frontiers of Architectural Research, 9(4): 872-889.

23. ONNOM W., TRIPATHI N., NITIVATTANANON V., NINSAWAT S., 2018, Development of a Liveable City Index (LCI) Using Multi Criteria Geospatial Modelling for Medium Class Cities in Developing Countries, Sustainability, 10(2): 1-19. 
24. OWUSU T. Y., 1998, To Buy or Not To Buy: Determinants of Home Ownership among Ghanaian Immigtants in Toronto, Canadian Geographer, 42(1): 40-52.

25. QU Y., JIANG G., ZHAO Q., MA W., ZHANG R., YANG Y., 2017, Geographic identification, spatial differentiation, and formation mechanism of multifunction of rural settlements: A case study of 804 typical villages in Shandong Province, China, Journal of Cleaner Production, 166: 1202-1215.

26. STEINNES D. N., 1978, A simulataneous econometirc model of the intraurban location of employment and residence, Regional Science Perspectives, 8(2): 101-105.

27. TAN S., LI Y., SONG Y., et al., 2017, Influence factors on settlement intention for floating population in urban area: a China study, Quality \& Quantity, 51(1): 147-176.

28. TAO L., HUI E. C. M., WONG F. K. W., CHEN T., 2015, Housing choices of migrant workers in China: Beyond the Hukou perspective, Habitat International, 49: 474-483.

29. WANG Y., JIN C., LU M., LU Y., 2017, Assessing the suitability of regional human settlements environment from a different preferences perspective: A case study of Zhejiang Province, China, Habitat International, 70: 1-12.

30. WANG Y., ZHU Y., YU M., 2019, Evaluation and determinants of satisfaction with rural livability in China's less-developed eastern areas: A case study of Xianju County in Zhejiang Province, Ecological Indicators, 104: 711-722.

31. WENG Y., ZENG Y., LIN W., 2021, Do rural highways narrow Chinese farmers' income gap among provinces?, Journal of Integrative Agriculture, 20(4): 905-914.

32. WU J., YU Z., WEI Y. D., YANG L., 2019, Changing distribution of migrant population and its influencing factors in urban China: Economic transition, public policy, and amenities, Habitat International, 94: 102063

33. YANG R., LIU Y., LONG H., QIAO L., 2015, Spatio-temporal characteristics of rural settlements and land use in the Bohai Rim of China, Journal of Geographical Sciences, 25(5): 559-572.

34. YANG Y., BAO W., LIU Y., 2020, Coupling coordination analysis of rural production-living-ecological space in the Beijing-Tianjin-Hebei region, Ecological Indicators, 117: 106512.

35. YI X., JUE W., HUAN H., 2021, Does economic development bring more livability? Evidence from Jiangsu Province, China, Journal of Cleaner Production, 293: 126187.

36. YUAN X., DU W., WEI X., YING Y., SHAO Y., HOU R., 2018, Quantitative analysis of research on China's land transfer system, Land Use Policy, 74: 301-308.

37. YUAN Y., WANG M., ZHU Y., HUANG X., XIONG X., 2020, Urbanization's effects on the urban-rural income gap in China: A meta-regression analysis, Land Use Policy, 99: 104995.

38. ZHAN D., KWAN M., ZHANG W., FAN J., YU J., DANG Y., 2018, Assessment and determinants of satisfaction with urban livability in China, Cities, 79: 92-101.

39. ZHENG S., FU Y., LIU H., 2006, Housing-choice hindrances and urban spatial structure: Evidence from matched location and location-preference data in Chinese cities, Journal of Urban Economics, 60(3): 535-557.

40. ZHOU D., XU J., LIN Z., 2017, Conflict or coordination? Assessing land use multi-functionalization using production-living-ecology analysis, Science of The Total Environment, 577: 136-147.

41. ZHOU X., 2014, Increasing Returns to Education, Changing Labor Force Structure, and the Rise of Earnings Inequality in Urban China, 1996-2010, Social Forces, 93(2): 429-455.

42. ZHOU Y., GUO Y., LIU Y., WU W., LI Y., 2018, Targeted poverty alleviation and land policy innovation: Some practice and policy implications from China, Land Use Policy, 74: 53-65.

43. ZOU L., LIU Y., WANG J., YANG Y., 2021, An analysis of land use conflict potentials based on ecological-production-living function in the southeast coastal area of China, Ecological Indicators, 122: 107297. 